\title{
A Review of Inclusive Education Contents included in Teacher Education Courses: Bangladeshi Context
}

\author{
Md Shahrier Haider ${ }^{1}$, Jannatul Ferdous ${ }^{2}$ \\ ${ }^{1}$ Assistant Professor, Institute of Education and Research, University of Dhaka, Bangladesh \\ ${ }^{2}$ Special Educator, Canadian Trillinium International School, Dhaka
}

\begin{abstract}
The purpose of the study is to explore the contents of inclusive education in different teacher education programs in Bangladesh. Here the researcher intended to review all the existing curriculum of teacher education programs and review the contents that are related with inclusive education. Three types of tools were developed to justify and support the research questions. Findings of the study show, regarding the contents of inclusive education, there are three different situations exist in teacher education programs. One situation is, some teacher education programs provide a full course of credit hours on inclusive education; another is, some teacher education programs have included some contents of inclusive education that is relevant with inclusive education fully or partially; and the other situation is no content is included at all in some teacher education programs. The contents are fairly contextualized but inclusive education specialists addressed some more modifications that can make it more contextualized and give the participants to get the opportunity to have hands on experience.
\end{abstract}

\section{Background of the Study}

Inclusive education, emerged from social model of disability, refers to a process of increasing the active participations of all children regardless of age, gender, ethnicity, language, disability, specific health issues (HIV and TB) and so on (Centre for Studies in Inclusive Education 2000) . It acknowledges that every child is different and that the school and the education system need to change or modify in order to meet the individual needs. Inclusion does not make everyone similar but means to make the system flexible (Save the Children, 2002).

Practicing inclusive education is increasing dramatically for last few decades. The effectiveness of teacher preparation courses in catering for diversity has become a key focus in many recent reports. It has been reported that between $25 \%$ and $40 \%$ of new graduate teachers in western societies quit or burn out within three to five years of job (Ewing \& Smith, 2003). The concerning attrition rate of graduate teachers suggests that there are not only inadequate contents in teaching courses but also lack of support that are provided to the teachers in implementing inclusive education (Forlin \& Chamber, 2011). Therefore, in developing countries, the inclusion of children is only written in policies which are used only for enrollment but not at all implementing effectively into classroom practices (Sharma \& Deppeler, 2005; McConkey \& Bradley, 2010; Xu, 2012). As a result, a huge number of diverse children in developing countries are still staying out of school or dropped out before completing primary school cycle (Yu, Su, \& Lui, 2011).

To bring a change in the education of diverse children, it is necessary to prepare responsible and promising teacher for inclusive education. Within the education system teacher education plays a vital role to bring a change in current practice. A teacher should have a clear positive attitude toward inclusion that they can achieve from their preparatory level. Therefore, it is necessary that a teacher education program must have some necessary contents regarding inclusive education. However, there are not enough contents in different teacher education programs. If there are any, it is inappropriate to change teachers' attitude towards the learning need of diverse group of children.

\section{Problem statement}

This article mainly explored the contents related to inclusive education from the entire course design that is offered in different teacher training programs in Bangladesh. The main concern of this article is to explore the inclusive education contents of teacher education programs existing in Bangladesh and compare it with the global contextual concept of inclusive education. Moreover, it intended to identify the strength and weaknesses of those contents. Besides, what can be the suggestive ideas to make the contents more informative and supportive for the teacher is also a problem area of this study.

\section{Target population of inclusive education}

Bangladesh, in assistance with UNESCO-Dhaka office, had a consultative workshop in 2001 with different stakeholders and developed a working definition of inclusive education that gives us a contextual concept about inclusive education in the context of Bangladesh.

Inclusive Education is an approach to improve the education system by limiting and removing barriers to learning and acknowledging individual children's needs and potential. The goal of this approach is to make a significant impact on the educational opportunities for the students (i) who attended school but for different reasons could not achieve adequate learning and (ii) who did not attend schools but who could attend if families, communities, schools and education systems were more responsive to their specific needs (Ahuja \& Ibrahim, 2006).

In the context of Bangladesh, the target groups for inclusive education are children with disabilities, Girl Children, children in Ethnic Backgrounds and Socially Disadvantages children like street children, orphan children, nomadic communities, working children and such more.

\section{Volume 8 Issue 9, September 2019}

\section{www.ijsr.net}




\section{International Journal of Science and Research (IJSR) \\ ISSN: 2319-7064}

ResearchGate Impact Factor (2018): 0.28 | SJIF (2018): 7.426

\section{Objectives:}

The article aims to

1) Review the curricula of different Teacher Education programs in Bangladesh.

2) Investigate the similarities of those contents with the contextual concept of inclusive education.

\section{Significance of the study}

The article intends to review the curricula of different education program of Bangladesh to get a general idea if there are any contents directly or indirectly related to inclusive education. Reviewing the contents is necessary as Bangladesh has been trying to adopt the process of inclusive education (Sharma, et al, 2012) and many researchers (Hossain, 2008; Das \& Ochiai, 2012) found that teacher had nominal knowledge and understanding about disability and inclusive pedagogy. The study intended to unmasking the actual scenario of inclusive education courses included in various teacher education programs. Following the developed countries, Bangladesh has also enacted necessary law and legislation to support inclusive education (Ahsan \& Burnip, 2007) and the Government of Bangladesh has drawn up plans (for example PEDP-II) for educating more children with disabilities in the inclusion classrooms with regular peers (Kibria, 2005). But the actual scenario is emotively different. An article, published in newspaper, reported the unwillingness of enrolling students with disabilities since the lack of trained teachers, suitable and availability of teaching materials, disability friendly infrastructure and school environment (Quota for Disabled Students, 2013). Therefore, it is mandatory to follow a standard curriculum for instructing inclusive education in teachers' education program and the contents are needed to be equally standard in central as well as peripheral training programs. Considering this issue, the second objective of the study has investigated the similarities of those existing contents with the contextual concepts of inclusive education.

\section{Methodology}

Twenty-five relative course instructors were selected from Teachers Training Colleges (TTC), Primary Teachers Training Institutes (PTI) and universities. Selected participants were the instructor of the courses which had some inclusive education related contents. They gave their valuable opinion about the course contents and how contextually they are conducting it in the classroom. Ten specialists were selected to provide data about the similarities of those contents with the contextualized concept of inclusive education. Snowball sampling method was used to select the instructors of related course. Since the study focused only in exploring the contents of inclusive education, the institutions were selected purposively.

In this qualitative study, two types of data collection instruments were used. For the study, one checklist and structured interview schedule were administered to generate data. One structured interview schedule containing six openended questions was developed for course instructors and the other one had five open-ended questions which were developed for the inclusive education specialist. Data were analyzed and presented through thematic approach. The existence of the contents of inclusive education and if it is contextualized are the main theme to be discussed.

The result of this research could not be statistically generated because of number of sample and adapting thematic analytical method of data analysis. Also, as it is a qualitative study the findings and result will be projected in descriptive manner.

\section{Findings}

After reviewing the different curricula the resrarcher $\mathrm{s}$ have found that there are some full courses on inclusive education in some programs and in some other cases presense of some contents regarding inclusive education were evident. The list of culrricula that provide full course regarding inclusive education are as follows:

- Master of Education, Institute of Education and Research (IER), University of Dhaka

- Master of Education evening Program, IER, University of Dhaka

- Master of Education program, Institute of Education and Research (IER), Rajshahi University

- 1 year Master of Special Education Program, (MSEd), National University (NU)

The list of curricula that provide a few contents/ unist only regarding inclusive education are as following:

- Bachelor of Education (Honors) program, IER, University of Dhaka

- Bachelor of Education Program IERT, Chittagong University

- 4 years Bachelor of Education honors Program, Teacher Training College (TTC)

- 1 years Bachelor of Education Program TTC

- Diploma in Primary Education program of Primary Teacher Training Institute (PTI)

Exploring curricula of Institute of Education and Research (IER), University of Dhaka

There are three Curricula in Institute of Education and Research, University of Dhaka. All of those have given some concern in Inclusive Education contents in both honors and masters level of courses. Title and Number of the Course is PC: 111, Introduction to Education and it is a 4 Credit hours course. It has a full unit about inclusive education (IE)

Table 2: Content Analysis of IE in Introduction to Education

\begin{tabular}{l} 
PC: 111: Introduction to Education \\
\hline Concept of Inclusive Education \\
Nature \& scope of Inclusive Education; \\
Significance of Inclusive Education \\
Target group of Inclusive Education \\
Serving process of special needs of the target group \\
Facilitators' role in inclusive setting
\end{tabular}

Another course numbered and titled PC-113 Educational Psychology, a 4 credit hour course, also has a full unit (unit 9) that could be partially related with inclusive education.

\section{Volume 8 Issue 9, September 2019}




\section{International Journal of Science and Research (IJSR) \\ ISSN: 2319-7064}

ResearchGate Impact Factor (2018): 0.28 | SJIF (2018): 7.426

Table 3: Content Analysis of IE in Educational Psychology PC-113 Educational Psychology

Who are Exceptional children;

Concept of Mentally retarded, reading disable and gifted children; Problem of backward, slow and fast learners;

Causes of reading disabilities and remedial approaches to reading disabilities;

Education for exceptional children;

Guidelines for Teaching exceptional children in regular classroom Creativity: definition, components, characteristics of creative person, how to foster creativity.
Two full courses were found in both the regular/day Masters Program and the Evening Masters program. The course that has been introduced in regular masters program is numbered and titled as SpE 591: Inclusive Education: Trends and Issues.

Table 4: Content Analysis of Inclusive Education: Trends and Issues

Contents of SpE 591: Inclusive Education: Trends and Issues

Definition and concept of Inclusive Education: developmental perspective; Impairment disability Handicap; normalization, Integration Equalization of opportunity and inclusiveness; Special Educational Needs; Present situation; new trends and basic principles

Inclusive Education and Rights: different international declaration and laws

Addressing the barriers of Inclusive education: negative attitude; invisible in the community and school; cost, physical access and class size; poverty and gender discrimination

How can we support Inclusive Education: by promoting positive attitude, inclusive learning environment, positive role model; by supporting appropriate policy development, change in system in education

New thinking in Special Needs Education-guidelines for action: policy and organization; school factors; recruitment and training of educational personnel; external support services; priority areas; community perspective.

Every child is an individual: Barriers to learning; Social and medical view of disability; reducing disability; right to education, implication.

Assessing Needs: Hearing impairments, Visually impairment, Intellectual disability and cerebral palsy -warning signs, causes and action teachers can take

Responding to diversity: nine golden rules

Working together: School together; school culture; community group

Another full course of 3 Credits that has been named and titled as SpED 660 Inclusive Education, has been found in Masters program (evening). Though it is a departmental course of Special Education Department, it is open for all to take. The contents are as following:

Table 5: Content Analysis of Inclusive Education

Contents of SpED 660 Inclusive Education

Concept of special education, integration and inclusion, Inclusion- ensuring "Education for All"; IDEA and the development of inclusive education; UN and international declaration and Bangladesh context.

Different models of inclusive education; approaches studies in developed and developing countries; factors influencing development of inclusive education.

Managing classroom with diverse learners considering gender issue; indigenous issue; children with disabilities; working and street children; children from socially excluded groups, teachers' role to manage diverse learners.

Challenges and practices in inclusive education: nine golden rules; barriers to inclusive education; strategies to overcome the barriers, belief and attitudes of teachers, parents, family, and communities; initiatives taken in Bangladesh context.

Curriculum consideration: curriculum simplification, modification and adaptation, adjusting existing curriculum; differentiating the curriculum (Indented, Taught and learned curriculum)

Consultation and collaboration in inclusion; administrators, role of school leaders, activities and advocates, inter agency collaboration, skills for working together.

Exploring curriculum of Institute of Education and Research, Rajshahi University

The researcher explored in different universities of Bangladesh and found that Institute of Education and
Research in Rajshahi University offers a full course of 4 credits in their Masters program. This course is numbered and titled MEd-210: Inclusive Education.

Table 6: Content Analysis of MEd-210: Inclusive Education

Contents of M.Ed-210: Inclusive Education

Definition and concept of inclusive education: developmental perspective; impairment, disability, handicap; introducing with special educational need; normalization, integration, equalization of opportunity and inclusiveness.

Policy and legislation: International: IDEA and the development of inclusive education; UN and international declaration like The Universal declaration on human rights (1948), UN Convention on the rights of the Child (1989), Education For All (1990), Salamanca Declaration (1994), Dakar Framework for Action (2000), Convention on the Rights of Persons with Disabilities (2006).

Present situation and inclusion in Bangladesh perspective; impact of the international declarations and legislations in Bangladesh; accounting the friction between policy and practice.

Challenges and practices of inclusive education: beliefs and attitudes of teachers, parents, family and communities, barriers to inclusive education; strategies to overcome the barriers, initiatives taken in Bangladesh context.

Curriculum consideration: Concept, scope and importance of curriculum consideration; ways of curriculum consideration; adjusting existing curriculum.

Managing classroom with diverse learners like: gender issue; indigenous; children with disability; working and street children;

\section{Volume 8 Issue 9, September 2019}

www.ijsr.net

Licensed Under Creative Commons Attribution CC BY 


\section{International Journal of Science and Research (IJSR) \\ ISSN: 2319-7064}

ResearchGate Impact Factor (2018): 0.28 | SJIF (2018): 7.426

children from socially excluded groups; teachers' role.

Approaches to inclusive education: factors influencing development of inclusive education, Approaches Strategies: developed and developing countries, New trends and basic principles, Nine Golden Rules, Models.

New thinking in special needs education: Policy and organization/ Administrators, School factors, Role of School leaders, Recruitment and training of educational personnel, External support services, Priority areas, Community perspective , Activists and

advocates, Inter agency collaboration, Skills for working together.

Exploring curriculum of the Institute of Education, Research and Training (IERT), Chittagong University Bachelor of Education Curriculum of the Institute of Education, Research and Training (IERT) in Chittagong University has also taken in consideration. After reviewing the curriculum it has been explored that there is a course numbered and titled as PC 501: Introduction to Education. It was evident that this curriculum is very much inspired by the B.Ed curriculum of Institute of Education and Research, University of Dhaka.
Table 7: Content Analysis of IE in PC 501, Introduction to Education

PC 501: Introduction to Education

Concept of Inclusive Education

Nature \& scope of Inclusive Education;

Significance of Inclusive Education

Target group of Inclusive Education

Serving process of special needs of the target group

Facilitators' role in inclusive setting

Exploring Curriculum of Masters of Special Education (MSEd) Program, National University

Bangladesh Protibondhi Foundation offers Master of Special Education (MSEd) program under the approval of National University. This program has a full course on Inclusive Education. The course is numbered and titled as Compulsory IV: Integrated and Inclusive Education and Innovative Ideas in Special Education.

Table 8: Content Analysis of Integrated and Inclusive Education and Innovative Ideas in Special Education

Compulsory IV: Integrated and Inclusive Education and Innovative Ideas in Special Education

Integrated Education for Disabled: definition and meaning of integrated education; Goals of integrated education; Handicapped factors, Models of integrated education program; factors influencing successful integration.

Integrated Education for Hearing Impaired Children: putting integration into practice, the academic, social integration of hearing impaired children, improving social skills and acceptance

Integrated Education for Visually Impaired Children: Growth and development of educational services for visually impaired children, Education in the least restrictive environment, define the role of regular teacher and the resource teacher in content to the visually impaired children.

Integrated Education for Mentally Retarded Children: putting integration for mentally integrated children, putting integration into practice, the academic and social integration mentally retarded children, improving social skills and peer, community acceptance.

Effective Teaching: ways of thinking about effective teaching, how pupils learn, setting up the learning experiences, taking account of pupil difference, classroom teaching qualities and test, relationship with pupils

Issues in Inclusion: concept of Inclusive Education, Barriers of Inclusive Education, Inclusion and differentiation, economical viability of Inclusive education, differentiation in action, Setting curriculum contact, parents involvement, the role of teacher

Innovative ideas in Special Education: Makaton, Augmentation and Alternative communication (AAC), Distance Training Package (PTP) etc.

Exploring curricula of Teachers Training College (TTC), National University

After reviewing the curricula of TTC the researcher found that they are not offering any inclusive education course in their program, however, there are two courses in 1 year bachelor of Education (B.Ed) program that contain some relevant contents on Inclusive Education. One is numbered and titled as PS100: Essential Teaching Skills that has only one topic in only a unit regarding the course and the contents are following:

Table 9: Content Analysis of IE in PS 100: Essential Teaching Skills

\begin{tabular}{|c|c|}
\hline \multicolumn{2}{|c|}{ 1 year Bachelor of Education (B.Ed) } \\
\hline Course Details & Contents \\
\hline $\begin{array}{c}\text { Course number and title: PS 100 } \\
\text { Course name: Essential Teaching } \\
\text { skills }\end{array}$ & $\begin{array}{c}\text { Including lagged behind or } \\
\text { underprivileged children: } \\
\text { learning needs analysis and } \\
\text { to meet the learning need of } \\
\text { those children and the } \\
\text { strategies to meet the } \\
\text { demands. }\end{array}$ \\
\hline $\begin{array}{c}\text { Unit 7- Class management with a } \\
\text { huge number of students }\end{array}$ & \begin{tabular}{c} 
tond \\
\hline
\end{tabular} \\
\hline
\end{tabular}

Another course of 1 year Bachelor of Education (B.Ed) program that is numbered and titled as ES 101: Secondary Education, curriculum and child development has also come to the consideration of the researcher. It has some topic that may help to include different target groups in regular classroom. Unit 3 of this course has 7 topics and 4 of them are relevant to inclusive education.

Table 10: Content Analysis of IE in ES 101: Secondary Education, Curriculum and Child Development

\begin{tabular}{|c|c|}
\hline \multicolumn{2}{|c|}{1 year Bachelor of Education (B.Ed) } \\
\hline Course Details & Course contents \\
\hline Course number and title: ES 101 & People of minorities, \\
Village children, \\
$\begin{array}{c}\text { Course name: Secondary Education, } \\
\text { curriculum and child development }\end{array}$ & $\begin{array}{c}\text { Underprivileged } \\
\text { children in urban areas, } \\
\text { Total marks: } 100\end{array}$ \\
$\begin{array}{cc}\text { Children with special } \\
\text { educational need. }\end{array}$ \\
\cline { 1 - 2 } Bnit 3: Problems in secondary education \\
Bangladesh
\end{tabular}

Apart from these, TTC also offers 4 year Bachelor of Education program. The researcher also took those curricula under consideration. It has been explored it has no content 


\section{International Journal of Science and Research (IJSR) \\ ISSN: 2319-7064}

ResearchGate Impact Factor (2018): 0.28 | SJIF (2018): 7.426

directly related with inclusive education but in a course titled Educational Psychology part 2 there is a section named Exceptional children offers some contents about mainstreaming the disable child.

Table 11: Content Analysis of IE in Educational Psychology Part 2

\begin{tabular}{|c|c|}
\hline Course Details & Contents \\
\hline Course name: & $\begin{array}{l}\text { Who are the superior intelligence children, } \\
\text { characteristics of superior intelligence, role }\end{array}$ \\
\hline Psychology Part & of a teacher \\
\hline & Low intelligence children: who are the low \\
\hline Total marks: 100 & $\begin{array}{l}\text { intelligence children; characteristics of those } \\
\text { children; role of a teacher }\end{array}$ \\
\hline Unit: 4: & Lagged behind children: who are the lagged \\
\hline $\begin{array}{l}\text { Exceptional } \\
\text { children }\end{array}$ & $\begin{array}{l}\text { behind children; characteristics of lagged } \\
\text { behind children; role of a teacher to bring }\end{array}$ \\
\hline & Disable child: who are the disable child; \\
\hline & $\begin{array}{c}\text { classification of disable child; } \\
\text { Social status of a disable child in }\end{array}$ \\
\hline & $\begin{array}{l}\text { Bangladesh; management and placement of a } \\
\text { disable child in the normal school and role of } \\
\text { a teacher }\end{array}$ \\
\hline
\end{tabular}

\section{Exploring the curricula of Primary Teachers Training Institutes (PTI)}

Primary Teachers Training Institutes are the institutes that provide training to the teachers of primary levels. Currently two programs named Certificate in Education (C-in-Ed) program and Diploma in Primary Education (DPEd) program are running in PTIs. There are 67 PTIs that have already introduced the DPEd program for their participants. The researcher reviewed the curriculum of DPEd program and found that a course titled Professional Studies Part 1 has only a unit named Inclusive Education. It's a course of 11 credit hours and 165 hours sessions. The inclusive education contents of this course are given below:

Table 12: Content Analysis of IE in Professional Studies Part 1

\begin{tabular}{|c|c|}
\hline \multicolumn{2}{|c|}{ Diploma in Primary Education (DPEd) program } \\
\hline Name of the Course: Professional Studies part 1; Session: 165 \\
hours
\end{tabular}

\section{Discussion}

This study has found three different situations in teacher education programs. Some teacher education programs have provided a full course on inclusive education where as some teacher education programs have included some contents of inclusive education which are fully or partially relevant with inclusive education; and in the third situation some teacher education programs have not included any topic of inclusive education at all.

\section{Existence of Inclusive Education Contents}

One of the objectives of this study was to review the existing curricula of teacher education programs to explore the contents of inclusive education. This study found that though all the instructors/teachers are aware of promoting inclusive education but the curricula do not have enough contents to cover it up in the context of Bangladesh.

Despite the fact that, the government of Bangladesh is committed to implement inclusive education at all level, it is necessary for every teacher education program to provide strategically implementable ideas on inclusive education to the pre-service or in-service teachers. But the C-in-Ed program of PTI and 1 year Masters Program of TTC have no content related with inclusive education. Moreover, the 4 year B.Ed program offers a unit of a course that is concerned about mainstreaming of disabled children rather than inclusive education as it only provides techniques for managing different disable children. Therefore, when the teachers are still not prepared, it is critical to expect that the policies regarding inclusive education can be implemented effectively.

\section{Contextualized Contents}

This study also tends to find out how these contents are relevant with the contextual concept of inclusive education in Bangladesh. There are some interesting issues such as existence of inclusive education contents but not contextualized with national aspects, addition of contextualized contents but not being instructed from pragmatic perspective.

To support their curriculum, the PTI instructors of DPEd program claimed that the contents are contextualized enough in the context of Bangladesh. Inclusive Education specialists also agreed that the IE contents of PTI curriculum are quite contingent and the instructors can make it more contextual, relevant and supportive for the teachers with their effective and better presentation. Nevertheless, it can be assumed that the role of instructors can play a vital role to support the teachers in the successful implementation of inclusive education contents.

On the other hand, it is found that the topics of inclusive education that are included in TTC are not much contextualized rather it is more generalized and these contents are too scanty to favour a teacher in his inclusive classroom. To support this statement, one of the inclusive education specialists' opinion can be quoted:

The curriculum of TTC focuses only the learning need of 'normal' children in regular classroom. Contents regarding inclusive education have been included in primary teacher education program after recent revision but the curricula for secondary education are still not in concern.

This study identifies two different aspects to discuss various inclusive education courses taught in different universities. Inclusive education specialists focused that MSEd program under the affiliation of National University emphasized on mainstreaming rather than inclusive education. It is evident from literature that the contents of inclusive education 


\section{International Journal of Science and Research (IJSR) \\ ISSN: 2319-7064}

ResearchGate Impact Factor (2018): 0.28 | SJIF (2018): 7.426

curriculum can help the learners to develop a proper attitudes toward the profession they might select (Tanner \& Tanner, 1980) and pre-service teacher can be a precious negotiator to implementing inclusive education in school settings. Considering the specialist's opinion regarding MSEd program of NU, it is recommended for a curriculum revision to make it more resourceful with inclusive education contents because a curriculum is considered as a first step for changing the attitude of teachers towards inclusive education.

Both the course teachers and inclusive education specialists agreed that the contents of inclusive education course for day program in Institute of Education and Research of Dhaka University are much theoretical and provided a less opportunity to give hands on activity. There exists some topics on law and legislation of inclusive education; however, implementation and implication issues in Bangladesh of those law and legislations were absent. An inclusive education specialist said:

If the curriculum only discusses the international perspective, participants may not be able to execute the knowledge in their real life profession although they completed a full course on inclusive education.

The curricula which are revised or developed recently were contextualized enough rather than the curricula which are formerly revised. For example, the curriculum of inclusive education that has been followed for evening Masters Program in Institute of Education and Research of Dhaka University is well contextualized as it is revised lately. But inclusive education specialists addressed more modifications that can make it more contextualized and give the participants to get the opportunity to have hands on experience. In comparison of these two curricula of IER, it is found the 3 credit hours course of evening M.Ed program is much contextualized then the 4 credit hours course of Day M. Ed program. Moreover, a full core course should be included in the regular Honors Program that is urged by an inclusive education specialist of IER.

Besides, the curriculum that is followed in Institute of Education and Research of Rajshahi University is also considered as contextualized by the course instructors and inclusive education specialist as well since it was developed to meet the professional demand of in-service teachers. The course contents are selected accordingly and as mention by course teacher the contents have a scope to discuss these in the current context of Bangladesh.

Apart from these, another perspective is including inclusive education contents in honors level. Institute of Education and Research of Dhaka University and Institute of Education, Research and Training of Chittagong University introduced the concept of Inclusive Education in an introductory course. Teachers believed that as these are the introductory contents these are made contextual by their own efforts. They use multi dimensional teaching learning approach to make to contents more effective for the students. As there is a growing concern internationally if the teachers receive for inclusion concept adequately (Lancaster \& Bain, 2007), the contents of inclusive education in Rajshahi
University can be considered positively for others to revise their own.

\section{Recommendations}

This study offers following recommendations regarding Inclusive education courses existing in various teacher education programs:

More contents regarding inclusive education should be included and make those contextual to get maximum benefit from those. Duration of sessions should also be increased with time and credit hours so that instructors get more time to cover those contents more effectively with some hands on experiences.

Contents should be revised in regular interval so that recent issues are not been neglected. As curriculum is an ongoing process, it should have the opportunity to modify frequently in the basic of recent critical issues.

Recent issues and practices in inclusive education should be included in curriculum. Other contents like laws and legislations, and barriers of inclusive education should be conducted more contextually by using multidimensional teaching learning approach such as brain storming, visiting inclusive schools and making reports based on current study of Bangladesh.

As curriculum is a dynamic process it should be updated regularly. Therefore, the curriculum committee should be aware of the latest critical issues of inclusive education and work on updated it in regular interventions.

\section{Conclusion}

In this world, a person can be a member of different groups, nation or geographical areas but none of the identity can never be the only identity to describe that person (Sen, 2004,). So, it is the responsibility of every stakeholder of education sectors to promote equity to ensure the educational right of diverse groups of people. Therefore, inclusion can be a possible solution to mitigate these existing inequities. Without teacher development the implementation process of inclusive education is difficult to embrace and total plan will be flounder. For that, including the concept of inclusive education adequately according to the context of Bangladesh and provide an effective guidelines in the curriculum of teacher education to conduct the contents or course can be prove helpful to make it effective in implementation level. So, supportive and informative contextualize contents along with some necessary conducting teaching strategies are the recent demand.

\section{References}

[1] Ahsan, M T \& Burnip, L. (2007). Inclusive Education in Bangladesh. Australasian Journal of Special Education. 31. 61-71. 10.1080/10300110701255807.

\section{Volume 8 Issue 9, September 2019}

www.ijsr.net

Licensed Under Creative Commons Attribution CC BY 
[2] Ahuja, A. \& Ibrahim, M.D. (2006). An Assessment of Inclusive Education in Bangladesh. Dhaka: UNESCODhaka.

[3] Das, A. \& Ochiai, T. (2012). Effectiveness of C-in-Ed Course for Inclusive Education: Viewpoint of In-service Primary Teachers in Southern Bangladesh, Electronic Journal for Inclusive Education, 2 (10), 23-32.

[4] Ewing, R. and Smith, D. (2003). Retaining quality beginning teachers in the profession. Citeseerx.ist.psu.edu. Available at: http://citeseerx.ist.psu.edu/viewdoc/download?doi=10.1. $1.498 .7105 \& \mathrm{rep}=\mathrm{rep} 1 \&$ type $=$ pdf

[5] Ewing, R. and Smith, D. (2003). Retaining quality beginning teachers in the profession. [online] Citeseerx.ist.psu.edu. Available at: http://citeseerx.ist.psu.edu/viewdoc/download?doi=10.1. $1.498 .7105 \&$ rep $=$ rep $1 \&$ type $=$ pd

[6] Forlin, C. \& Chambers, D. (2011). Teacher Preparation for Inclusive Education: increasing Knowledge but raising concerns, 18

[7] Hossain, J. (2008). Special Education in Bangladesh: Present Trend and Future Needs. Paper presented in Asia-Pacific Seminar on Education for Individuals with Disabilities. Yokohama, Japan.

[8] Centre for Studies in Inclusive Education (2000), Index for Inclusion: Developing learning and participation in schools, Bristol, United Kingdom.

[9] Kibria, G. (2005). Inclusion education and the developing countries: The case of Bangladesh. The Journal of the International Association of Special Education, 6(1), 43-47.

[10] Lancaster, J., \& Bain, A. (2007). The design of inclusive education courses and the self-efficacy of preservice teacher education students. International Journal of Disability, Development and Education, 54(2), 245-256.

[11] Mcconkey, Roy \& Bradley, A. (2010). A Long Walk to School: International Research on Inclusive Education across the Life-Span. Promoting inclusive education in low income countries. 7-26.Xu, 2012

[12] Save the children (2002), School for All, Retrived from: https://www.eenet.org.uk/resources/docs/schools_for_al 1.pdf

[13] Sen A. (2004). Elements of a Theory of Human Rights, Philosophy and Public Affairs. 2004;32.

[14] Sharma, U; Forlin, C.; Deppeler. J \& Xue, Y.G (2012). Reforming Teacher Education for Inclusion in Developing Countries in the Asia-Pacific Reagon. Asian Journal of Inclusive Education 1(2)

[15] Tanner, D., \& Tanner, L. (1980). Curriculum development: Theory into practice. Columbus, $\mathrm{OH}$ : Merrill.

[16] UNESCO Dhaka Office: biennial progress report (Ed.). (2001). biennial progress report 2000-2001.

[17] Xu, J. C. (2012). Development of learning in regular class and measure of teacher education in China. In $\mathrm{C}$. Forlin (Ed.), Future directions for inclusive teacher education (pp.33-42). New York: Routledge.

[18] Yu, L., Su, X., \& Liu, C. (2011). Issues of teacher education and inclusive education in China. Prospects, 41, 355-369 